new treatments development are supported by funding source other than industry.

Abstract AB0614 - Table 1

\begin{tabular}{lcccccc}
\hline Phase & $\begin{array}{c}\text { Worldwide } \\
(\mathbf{n})\end{array}$ & $\%$ & $\begin{array}{c}\text { EU } \\
(\mathbf{n})\end{array}$ & $\%$ & $\begin{array}{c}\text { Spain } \\
(\mathbf{n})\end{array}$ & $\%$ \\
\hline Early Phase & 7 & 1.1 & 2 & 1.2 & 0 & 0.0 \\
1 & & & & & & \\
Phase 1 & 76 & 12.4 & 17 & 10.2 & 3 & 5.5 \\
Phase 1/2 & 24 & 3.9 & 4 & 2.4 & 0 & 0.0 \\
Phase 2 & 143 & 23.4 & 57 & 34.3 & 23 & 41.8 \\
Phase 2/3 & 15 & 2.5 & 5 & 3.0 & 1 & 1.8 \\
Phase 3 & 76 & 12.4 & 34 & 20.5 & 21 & 38.2 \\
Phase 4 & 47 & 7.7 & 7 & 4.2 & 3 & 5.5 \\
No data & 223 & 36.5 & 40 & 24.1 & 4 & 7.3 \\
\hline
\end{tabular}

* The percentages have been rounding

Conclusions: Europe participate in more than a quarter of Lupus clinical studies and Spain is the third European country participating in those clinical studies.

New treatment development studies are the main CT performed worldwide and the percentage is even higher in Spain. Regarding the study phase, the distribution of CT in Europe and Spain are similar although phase I studies in Spain are less frequent.

From all studies registered, the majority are non-industry sponsored studies. In Europe and in Spain the situation is the opposite, as $87.3 \%$ of the studies are pharma-sponsored studies.

Disclosure of Interest: N. Bahamontes-Rosa Shareholder of: GSK, Madrid, Spain, Employee of: GSK, Madrid, Spain, A. Muñoz Jiménez Employee of: Hospital Virgen del Rocio, F. Hidalgo Shareholder of: GSK, Madrid, Spain, Employee of: GSK, Madrid, Spain, M. Pardo Shareholder of: GSK, Madrid, Spain, Employee of: GSK, Madrid, Spain, J. Diago Cabezudo Shareholder of: GSK, Madrid, Spain, Employee of: GSK, Madrid, Spain

DOI: 10.1136/annrheumdis-2018-eular.2893

\section{AB0615 $\quad$ CHANGES IN SOMATOSENSORY EVOKED POTENTIALS IN PATIENTS WITH PRIMARY SJOGREN'S SYNDROME}

E. Dziadkowiak ${ }^{1}$, A. Sebastian ${ }^{2}$, M. Wieczorek ${ }^{3}$, E. Kusińska ${ }^{1}$, M. WaliszewskaProsół $^{1}$, P. Wiland ${ }^{2}$, M. Ejma ${ }^{1} .{ }^{1}$ Department of Neurology; ${ }^{2}$ Department of Rheumatology and Internal Medicine, Wroclawc Medical University; ${ }^{3}$ Department of Geoinformatics and Cartography, Institute of Geography and Regional Development, Wrocław, Poland

Background: Primary Sjogren's syndrom (pSS) is a chronic autoimmune disease, which, in addition to impaired function of exocrine glands, can affect other organs including nervous system.

Objectives: The aim of the study was to establish whether in patients with pSS without central nervous system (CNS) involvement, the function of the central portion of the sensory pathway can be challenged.

Methods: In 33 patients diagnosed with pSS without clinical features of CNS damage and normal head CT scan, somatosensory evoked potentials (SEP) were studied. The results were compared to other clinical parameters of the disease, particularly to immunological status. The control group consisted of 20 healthy volunteers selected with respect to age and sex.

Results: Mean latency of all components of SEP were considerably prolonged in patients compared to the control group. Mean interpeak latency N20-N13 (duration of central conduction TT) did not differ significantly between the groups. However, in the study group, mean amplitude of N20P22 and N13P16 was significantly higher compared to healthy individuals. In patients with PSS, significant differences in SEP parameters depending on duration of the disease, duration of arthralgia and presence of SSA and SSB antibodies were noted. No significant differences in mean SEP parameters were observed with respect to skin lesions, xerophthalmia, current joint pain and swelling, focus score, levels of C3 and C4 complement components, ESR, CRP and presence of Ro52 antibodies.

Conclusions: The authors confirmed central nervous system involvement often observed in patients with pSS. They also showed dysfunction of the central sensory neuron as a difference in amplitude of cortical response, which indicates subclinical damage to the CNS.

Disclosure of Interest: None declared

DOI: 10.1136/annrheumdis-2018-eular.3133

\section{AB0616 \\ THE CORRELATION BETWEEN FOCUS SCORE AND ULTRASONOGRAPHY OF MAJOR SALIVARY GLANDS IN PRIMARY SJÖGREN SYNDROME}

A. Sebastian ${ }^{1}$, J. Silicki ${ }^{2}$, A. Hałoń ${ }^{3}, \underline{\text { P. Wiland }}{ }^{1} .{ }^{1}$ Department of Rheumatology and Internal Medicine; ${ }^{2}$ Department of General and Paediatric Radiology; ${ }^{3}$ Division of Pathomorphology and Clinical Cytology, Department of Pathomorphology, Wroclawc Medical University, Wrocław, Poland

Background: Currently, the role of salivary gland ultrasonography (SGUS) in the diagnosis of primary Sjögren's syndrome (pSS) is being determined. So far, in none of the proposed classification criteria for pSS SGUS is taken into consideration. The most recent analyses of patients show that SGUS can prove to be useful in the identification of even early forms of pSS.

Objectives: We analized the SGUS changes in patients with pSS and its correla tions with focus score (FS) of minor salivary glands and immunological and laboratory profile.

Methods: We included 68 patients with pSS in the mean age of 51 , based on the classification criteria from 2002

Results: In 33 (48\%) patients were abnormal findings in major salivary glands detected (table 1). Scattered hypoechogenic changes of different size were the most common observed changes in SGUS, mainly in parotid glands.

Abstract AB0616 - Table 1. Abnormal images in salivary and mandibular glands in patients with pSS.

\begin{tabular}{ll}
\hline Number of patients - 33 & $\begin{array}{l}\text { Parotid and submandibular } \\
\text { glands }\end{array}$ \\
\hline Changes in SGUS & $\begin{array}{l}\text { Parotid glands } 23 \text { patients } \\
(70 \% \text { of changes })\end{array}$ \\
& $\begin{array}{l}\text { Submandibular glands } 10 \text { patients } \\
(30 \% \text { of changes })\end{array}$ \\
SGUS changes: & $48 \%$ of changes \\
- gland enargement & $85 \%$ of changes \\
- scattered hypoechogenic changes of different & \\
size & $6 \%$ of changes \\
- fibrosis & $15 \%$ of changes \\
- lymph glands & $12 \%$ of changes \\
- gland atrophy & $3 \%$ of changes \\
- ducts enlargement &
\end{tabular}

The FS was significantly higher in patients with changes in SGUS compare to the patients with normal images of major salivary glands (2.6 SD 1.3 vs 1.8 SD 1.2 $\mathrm{p}=0.02$ ).

In patients with SGUS abnormalities the hypergammaglobulinemia was mos often observed $(1.7 \mathrm{~g} / \mathrm{dl}$ vs $1.2 \mathrm{~g} / \mathrm{dl} ; \mathrm{p}=0.02)$. There was not the correlation between changes in major salivary glands and age $(p=0.5)$, CRP value $(p=0.1)$, ESR value $(p=0.1)$, with blood cell count $(p=0.1)$, rheumatoid factor $(p=0.1)$, dry eye $(p=01$.$) , oral dryness (p=0.2)$, anty-SSA antibodies $(p=0.5)$, anty-SSB antibodies $(p=0.2)$, anty-Ro52 antibodies $(p=0.4)$ observed.

Conclusions: SGUS is a useful tool in patients with pSS. The abnormal images in SGUS of major salivary glands correlated with focus score of minor salivary glands and hypergammaglobulinemia but not with specific antibodies.

Disclosure of Interest: None declared

DOI: 10.1136/annrheumdis-2018-eular.3196

\section{AB0617 ACROSS-SECTIONAL STUDY OF NAILFOLD MICROVASCULAR CHANGES IN INDIAN PATIENTS WITH RNP+ LUPUS AND MCTD USING NAILFOLD VIDEOCAPILLAROSCOPY}

P.P. Chebbi ${ }^{1}$, R. goel ${ }^{1}$, R. aithal ${ }^{1}$, G. mahasampath ${ }^{2}$, D. danda ${ }^{1}{ }^{1}$ Clinical Immunology and Rheumatolgy, ${ }^{2}$ Biostatistics, Christian Medical college, Vellore, India

Background: Nailfold Capillary (NFC) changes represent degree of microvascu lar involvement in autoimmune connective tissue diseases. Anti U1-RNP is associated with specific internal organ involvement in SLE. Nailfold capillaroscopy may objectively predict the systemic microvascular abnormalities in SLE patients with positive Anti U1-RNP antibody.

Objectives: To study nailfold microvascular changes (NFVC) in SLE patients with RNP +and compare them with NFVC changes observed in patients with RNP negative SLE and Mixed connective tissue disease (MCTD).

Methods: Nailfold videocapillaroscopic (NFVC) examination (Optiliamediscope, 200X) was performed in consecutive patients satisfying classification criteria of 